\title{
The theory fusion between information technology and contemporary education
}

\author{
Yu Liü, a \\ ${ }^{1}$ Jilin Agricultural University, Changchun City, Jilin province, China \\ a37373021@qq.com
}

Keywords: Information technology, Education, Contemporary education, Depth fusion

\begin{abstract}
Information technology provides a good learning environment for the teaching, to really build up the students' subject status, the autonomous learning, inquiry learning, collaborative learning is able to realize, greatly stimulated the students' learning motivation, cultivate the innovative spirit and practice ability. Reading, writing, oral communication and comprehensive study teaching content with the support of information technology has a broad space, more efficient, deeply into the students' literacy. Information technology and curriculum integration is an important issue in front of us, should delve into the teaching design, teaching strategy, form the teaching mode, teaching should be combined with the theory and practice, in order to promote the teaching of radical change.
\end{abstract}

\section{Introduction}

Nowadays, computer and network communication as the core of information technology is widely applied in various fields of society, information acquisition, analysis, processing, distribution and application ability will become the measure of modern basic ability and an important symbol of culture. Cultivate the students' information literacy, improve students' ability of processing and using information, become an important content and task of education in the new century. In primary and secondary school courses in information technology is the purpose of "to make the students have access to information, information transmission, and application of information ability [1]. Cultivating students' good information literacy, the information technology as a means of support lifelong learning and cooperative learning, in order to adapt to the information society study, work and life lay the necessary foundation. "Information technology courses is one of the teaching task, the integration of information technology and other disciplines, encourage widely used in other disciplines teaching information technology [1]. In information-based learning environment, to integrate information technology curriculum and teaching, to deepen the reform of the course teaching, improve teaching efficiency and cultivate the students' overall quality is of great significance.

\section{The development of information fusion technology and the education teaching process}

The history of education information is a dynamic process, is information technology and the development of the education teaching constantly fusion process. Combined with the United Nations educational, scientific and cultural organization (UNESCO) in 2005 pointed out that the development of integration of information technology and education teaching process theory, the four phases of comparative analysis our country's actual development condition, education of information technology in teaching can be further understanding of the integration of the law of development.

Impact of information technology in education field "off" stage, the characteristics of information fusion technology and the education teaching is still the teacher as the center, the information technology as an auxiliary tool only assist the teacher in the classroom teaching, information technology is not in the school education teaching and management of being widely accepted and used. Basic knowledge of computer and office software operation, for example, E-mail use, etc. Join the teaching content, teacher's blackboard writing PPT presentation in lieu of, start preliminary application in school education management software, etc [2]. At present, the world's major developed countries and some developing countries have been spent in this stage, the role of 
information technology in education and teaching management has received widespread attention, the integration development of information technology and education teaching has become a common action in countries around the world. Most areas in China and the school has been basically through this stage, the major effect of the information technology to the education teaching has been widely accepted and, the introduction of information technology has become a common, proactive behavior.

Information technology gradually play a role in the education of "application" stage. In the "integration" stage, information fusion technology and the education teaching lies in promoting teachers' professional ability development and innovation of the teaching method based on the information technology environment [1]. At this stage, the teacher fully integrate information technology and classroom teaching, organize and conduct "take the student as the main body of learning activities, through positive guidance and the auxiliary, give full play to the students' autonomy and motivation, improve learning effect; At the same time, the use of information technology in teaching and management platform, web-based teaching and research work, manage their own learning process, improve teachers' information technology application ability. The part of the higher education information level of development in developed countries is in this stage, information technology has already been deep into the teaching process, in promoting teachers' professional ability development played a larger role [2]. Developed areas in our country, the eastern part of the school has already begun to enter the stage, using information technology to carry out the project-based collaborative learning and collaborative research network, has become more and more students and teachers.

In the "application" stage, information technology and education teaching mainly embodied in the education teaching and teaching management commonly used information technology to improve the teaching quality and improve the efficiency of management, the teacher began to pay attention to the introduction of information technology in the process of changing teaching methods, education departments and schools began to use information technology to support teacher training and professional development [2]. At this stage, the teacher to experience the advantages of information technology applied in teaching, but at this time is faced with information infrastructure and resources to meet the demand of obstacles. Most developed countries have spent in this stage, information technology is widely used in the education teaching and teaching management. Most areas in China and all kinds of schools are still in this stage, although the school have the infrastructure conditions, but because of the lack of adequate quality resources, makes the application of information technology in education is faced with "there is no car, the car is not available from" awkward situation.

Comprehensive information technology into education teaching and profound change stages of "innovation". In the stage of "innovation", fully integrate information technology education teaching mainly reflected in the information technology began to change teaching mode, schools and education institutions reconstruction of organization structure. In this stage, the students become the center of the learning activities, teaching activities and the organization of teaching contents are to be carried out around the promote students' learning and, at the same time, education departments at all levels and efficiency of school management is no longer as determined by the processing capacity of information technology, but its internal management structure and transaction process [3]. World minority education information development level of the leading developed countries (such as the United States) has begun to enter the stage, in 2010 the national education technology program (NETP 2010) clearly put forward "change power of American education -- learning", emphasize "by the technical support of major structural change, rather than evolutionary tinkering. "Visible, information technology and the fusion of the education teaching has been gradually thorough, in the United States supported by information technology education reform has not only is a kind of vision, but also a true reality. 


\section{Modern education technology and curriculum integration is an inevitable trend}

The combination of information technology and contemporary education has become a trend in the development of contemporary education, for the rapid development of China, is a rare opportunity, it is also a huge challenge. In order to realize the depth of the integration of information technology and contemporary education, must stand in the global strategic height, forward-looking planning, has it been possible to seize the opportunity, to achieve the leap development of education in our country.

The idea of information technology and contemporary education organic integration. Objectively, any new technology, will be mixed, information technology is no exception. In China, some people, even some educators, for the combination of information technology and education is a kind of negative cognition, especially the Internet addiction, network violence, lack of moral problems, such as virtual space more become an excuse for some rejects information technology. Mobile network information for some parents, teachers, seems to be a disaster [3]. Under such a thinking inertia, to realize the depth of the integration of information technology and education, obviously it is rather difficult, therefore, must strengthen the guidance on ideology, especially the relative lack of information technology knowledge, but they own the resources, has great influence on education of teachers, parents must emancipate the mind, change ideas. Otherwise, so-called education of information technology in depth fusion, after losing the most important social spiritual and psychological support, no amount of technology and financial investment, is unlikely to achieve the desired effect.

Role in the development of information technology in education innovation. System innovation is the prerequisite of technology innovation, and promotes the powerful tools for the new technology. On the one hand, to bring into full play the advantages of information technology in modern education, we must have to adapt to the related education supporting system, such as school system, degree system, examination system must keep pace with the Times, able to accommodate, support rather than discrimination, rejected the learning model based on information technology and educational way. On the other hand, it must be from the beginning to establish standard strict system, as much as possible to avoid appeared in the process of information technology in education and the fusion of negative issues [3]. At the end of the day, the information technology is to serve education; the purpose is to use him to more effectively achieve the goal of education. If system cannot save for a rainy day, there is a possible tool above purpose, pure descended into a form or even become a few ways to profit. On the other hand, it must be from the beginning to establish standard strict system, as much as possible to avoid appeared in the process of information technology in education and the fusion of negative issues.

Information technology is to serve education. All education technology based on the methods of education resources and education system of identification, development, organization and utilization, are through the management of these processes to facilitate students' learning [4]. The emergence and popularity of modern computer, not only promote the reform of education mode, education methods, it is important to promote the renewal of the education thought, education idea, the education system, teaching material and so on will also bring a revolutionary impact. It can be said that the modern education technology and curriculum integration is the inevitable trend of modern education technology development.

In the primary and secondary schools in the United States, the application of information technology of modern education technology is very common [4]:

1) In a variety of courses in the teaching process, the use of computer has been very naturally fusion among them, form combined book knowledge and social information, teachers' teaching and combining the self-exploration teaching ideas and teaching mode.

2) In all the schools of library and reference room, usually equipped with can directly on computer, the Internet as query information between teachers and students, the tools necessary to get information and knowledge.

3) Almost every discipline in the classroom teaching, using tools such as projector, multimedia computer. Teaching by the teacher some questions and assignments, teachers and students 
together to discuss and explore, and use tools such as computer at any time, to show the teaching content, knowledge exploration.

4) High school physics, chemistry, biology and so on also configure a number of computers in the lab. The students' experiment process can demonstrate, through the computer experimental data obtained from the experiments at any time using the computer for processing. In the elementary school science classes, students with a variety of playful toy, similar to see from the computer display, which is connected with the toy of various physical properties, such as trajectory, velocity, distance, temperature and pressure, etc. , let the students accepted in the process of very interested in learning about the knowledge.

From it, we can see that modern education technology represented by computer here really become teachers' teaching and students learning tools, played a high utility. Modern education technology is to better meet the needs of subject teaching in school is more and more widely used. Use computer, use of multimedia, network and other modern teaching equipment and technology, has become the teaching of internal demand.

\section{The integration of information technology and education mode}

Traditional focuses on teaching the knowledge and ability training system, pay attention to teach grammar vocabulary knowledge and language teaching material in a few words just as impart knowledge model, modern teaching attention to the cultivation of creative thinking, attaches great importance to the accumulation, comprehension and edification, attaches great importance to the utilization ability and the cultivation of language sense, takes student's practice, let the student active learning in the process of teaching, to explore.

The possibility of integration. Integration is refers to the elements within a system of overall coordination, mutual penetration, the elements make the system maximum benefit. Curriculum integration is to divide the various elements of teaching system and its various components form organic connection and become the whole process [5]. Curriculum integration theory to study sample subjects split the disadvantages of knowledge based administered content reform, aims to establish the organic relationship between disciplines. Such integration thought the discipline as a factor of teaching system, it is not inflict a course content in another course, but on the basis of considering the discipline characteristic, put a few related subject is integrated into consideration, to meet the same problem from different angles, coordinate with each other, mutual penetration, so that the discipline teaching system of teaching efficiency. To integrate the information technology curriculum and curriculum of primary and secondary schools, is on the study of subject knowledge as the carrier, the information technology course as a tool and means to infiltrate the discipline teaching, and at the same time of learning information technology course, and to cultivate students the comprehensive ability to solve the problem of discipline [5]. Therefore, the teacher in the concrete teaching process, on the one hand, pay attention to the subject or problem in real life, introducing with the practical background, arouse the students' interest in study of information technology, to deepen the understanding of information technology and knowledge. On the other hand, should also arrange some practical teaching activities, let the student through the Internet and other information means access to information, tools and information to learn how to use information analysis and processing information, and learn to communicate in activities, cooperate to complete the task, to train their innovative consciousness and innovative ability.

Teaching content problem. According to the specific characteristics of the teaching content, the discipline nature and by the teachers and students will be teaching content into various forms of valuable problems, and on the Internet, both inside and outside the class for students of inquiry-based learning set the logical starting point [6].

To explore the teaching process. Students actively obtain collated by teachers and placed on the network information, and other network data, after the access to basic knowledge, in classroom teaching, around the issues related to self exploration or collective discussion, teachers participate in and guide students to discuss with equal attitude, make the teaching process from the traditional inheritance to explore [6]. 
Networking of teaching activities. In the teaching activities, change the past teaching content mainly comes from the textbook single status, emphasis on training students to get material from the network resources, self transformation, restructuring, to create the ability of teaching content, form the ability and habit of students access to resources from the network.

The innovation of teaching. Network just environment, explore just means, teaching mode reform aims to cultivate students' innovative spirit [6]. Because of the reform, really the establishment of the student's main body status, learning autonomy, initiative and cooperative play, to cultivate students' innovative consciousness, innovative thinking and innovative personality.

As a new course, teachers and students are often unable to grasp its rule and method of study, therefore, I think we can set up a web page, the window of the inquiry learning helps the student to carry on the inquiry learning under network environment.

\section{Summary}

Looking to the future, the integration development of information technology and education teaching must become the theme of education information development in our country, and will lead the deep reform of the education teaching innovation and technology applications. In the face of this important opportunity and challenge, must continue to adhere to the construction of the future classroom, training future teachers, the development of future education idea, promote the depth of the education of information technology in teaching, in order to accelerate the development of education modernization process, promote the construction of a learning society.

\section{Acknowledgement}

This project, Research on the Stability of A Small World Network with Higher Order Time Delay, is supported by Research Initiation Fund of Jilin Agricultural University (Project No.: 2015043). Project Principal: Jing Zhou.

\section{References}

[1] J. Q. Sun, Advantages and disadvantages of multimedia teaching and traditional teaching method analysis, information technology, 2003, vol. 7, pp. 25-29.

[2] Q. R. Sui, Between the emerging multimedia teaching and traditional teaching, Jilin education, 2010, vol. 2, pp. 54-58.

[3] X. W. Ma, theory of classroom teaching of university information environment, journal of Xinjiang petroleum institute of education, 2004. Vol. 4, pp. 12-16.

[4] H. Y. Wang, Under the environment of information development of college teachers' teaching ability, Higher education in Jiangsu province. 2010. Vol. 2, pp. 54-58. .

[5] J. Ch. Wu, Autonomous collaborative teaching mode under the network environment research, computer education, 2010, vol. 12, pp. 23-26.

[6] W. Zh. Wen, Research-oriented teaching method under the environment of information exploration, Education information reference, 2008, vol. 14, pp. 56-59. 